Hydrol. Earth Syst. Sci. Discuss., 5, 1533-1566, 2008 www.hydrol-earth-syst-sci-discuss.net/5/1533/2008/

(C) Author(s) 2008. This work is distributed under the Creative Commons Attribution 3.0 License.
Hydrology and Earth System Sciences Discussions

Papers published in Hydrology and Earth System Sciences Discussions are under open-access review for the journal Hydrology and Earth System Sciences

\title{
Incorporating infiltration modelling in urban flood management
}

\author{
A. S. Jumadar, A. Pathirana, B. Gersonius, and C. Zevenbergen \\ UNESCO-IHE Institute for Water Education, Delft, The Netherlands
}

Received: 9 May 2008 - Accepted: 15 May 2008 - Published: 20 June 2008

Correspondence to: A. Pathirana (a.pathirana@unesco-ihe.org)

Published by Copernicus Publications on behalf of the European Geosciences Union.

\section{HESSD}

$5,1533-1566,2008$

Incorporating infiltration modelling in urban flood management

\section{A. S. Jumadar et al.}

\section{Title Page}

Abstract

Conclusions

Tables

14

4

Back
Introduction

References

Figures

$\rightarrow$

$>$

Close
Full Screen / Esc

Printer-friendly Version

Interactive Discussion 


\section{Abstract}

Increasing frequency and intensity of flood events in urban areas can be linked to increase in impervious area due to urbanization, exacerbated by climate change. The established approach of conveying storm water by conventional drainage systems has 5 contributed to magnification of runoff volume and peak flows beyond those of undeveloped catchments. Furthermore, the continuous upgrading of such conventional systems is costly and unsustainable in the long term. Sustainable drainage systems aim at addressing the adverse effects associated with conventional systems, by mimicking the natural drainage processes, encouraging infiltration and storage of storm water. In this study we model one of the key components of SuDS, the infiltration basins, in order to assert the benefits of the approach. Infiltration modelling was incorporated in the detention storage unit within the one-dimensional urban storm water management model, EPA-SWMM 5.0. By introduction of infiltration modelling in the storage, the flow attenuation performance of the unit was considerably improved. The study also examines the catchment scale impact of both source and regional control storage/infiltration systems. Based on the findings of two case study areas modelled with the proposed options, it was observed that source control systems have a greater and much more natural impact at a catchment level, with respect to flow attenuation, compared to regional control systems of which capacity is equivalent to the sum of source control capacity at the catchment.

\section{Introduction}

Integration of Sustainable drainage systems (SuDS) in storm water management is vital in improving the function of the whole urban water cycle and to mitigate water related disasters. Traditionally, such systems have been used to control runoff volumes and peaks for minor flood events. However, their performance in terms of handling bigger storm events can be improved by inclusion of conveyance systems that allow routing
HESSD

5, 1533-1566, 2008

Incorporating

infiltration modelling in urban flood management

A. S. Jumadar et al.

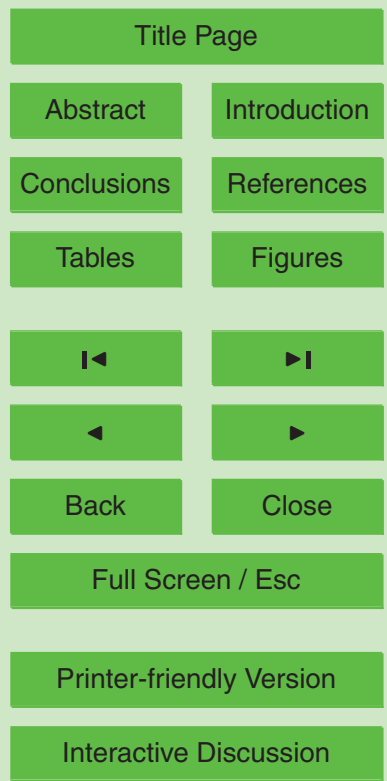


of flows that exceed their capacity and improving their storage capacity (Tourbier and White, 2007). A strong argument in favour of SuDS is the fact that they attempt to mimic the natural water cycle under pristine catchment conditions as opposed to traditional structural solutions that approach the problem by further unlinking the flow pathways 5 within natural system (e.g. low friction, impervious, storm water conveyers).

As the application of SuDS increases in urban areas, so will the requirement for their effective design and implementation. With that respect, accurate and easy to use tools for modelling such systems are crucial. Moreover, the modelling of the infiltration aspect, prevalent in such systems is essential in simulation of their performance with 10 respect to flow attenuation.

At present, one-dimensional urban drainage models such as MOUSE, developed by Danish Hydraulics Institute or EPA-SWMM, developed by the Unites States Environmental Protection Agency, do not allow the modeling of infiltration in detention storage (Elliott and Trowsdale, 2006). This hinders the direct use of these simple models by

engineers in the SUDS design process. In order to overcome this issue, in this study, we modify the EPA-SWMM 5.0 model to incorporate infiltration modeling in its storage unit object. EPA-SWMM 5.0 being a free and open source model makes it possible to implement our objective within the models computational source code.

Currently, sustainable drainage systems are designed for individual sites (S. G. Wal20

lis et al., 2003), hence as their adoption increases, their catchment scale impact will have to be examined and thus determine the performance of such systems within the context of the whole catchment. In this paper, an evaluation of the catchment scale impact of source and regional control storage systems is undertaken, in an effort to facilitate decision making in urban catchments, with a view of maximizing the flow at-
HESSD

$5,1533-1566,2008$

\section{Incorporating infiltration modelling in urban flood management}

A. S. Jumadar et al.

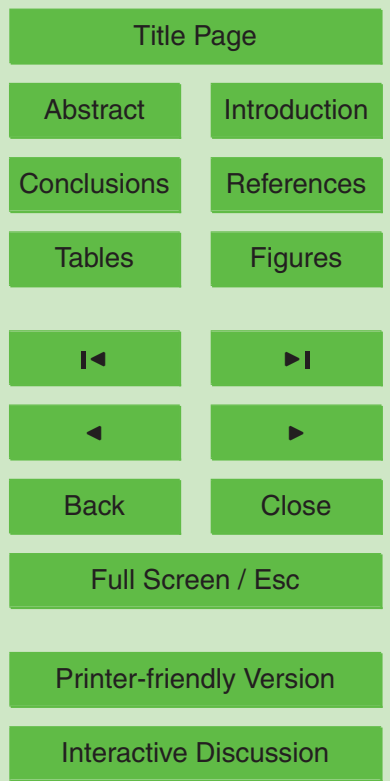




\section{Models for simulating infiltration in detention or infiltration basins}

The physical basis for infiltration process is provided by Richard's equation, a theory based on Darcy's equation of flow in porous media extended to the water movement in unsaturated zone. Treating soil water movement as one-dimensional in the vertical

5 direction, the h-based formulation of the Richard's model is:

$C(h, z) \frac{\partial h(z, t)}{\partial t}=\frac{\partial}{\partial z}\left[K(h, z) \frac{\partial h(z, t)}{\partial z}-1\right]$

where

$C(h)=d \theta(h) / d h$

$\theta=$ volumetric water content as a function of location and time, $t$

$10 h=$ soil capillary pressure head

$K=$ soil hydraulic conductivity

$z=$ vertical elevation above a certain datum

The Richard's equation governs the time dependent rate of infiltration into the soil, subject to antecedent soil moisture conditions in the soil profile, the rate of water appli-

15 cation at the soil surface, and the conditions at the bottom of the soil profile (Maidment, 2007).

Numerous simplified models have been developed for performing simulations related to water movement through the complex system in the unsaturated zone. For application in this study, we required a model that is based on the underlying physics of the process. Green-Ampt Model - a physically based equation, derived on the basis of Darcy's law (hence Richard's equation), was used.

Infiltration rate $f$, based on Green-Ampt equation and neglecting depth of ponding on the surface is:

$f=-K\left[1+\frac{\left(\theta_{s}-\theta_{i}\right) S_{f}}{F}\right]$

25 where

$F=$ accumulated infiltration

\section{HESSD}

$5,1533-1566,2008$

Incorporating infiltration modelling in urban flood management

A. S. Jumadar et al.

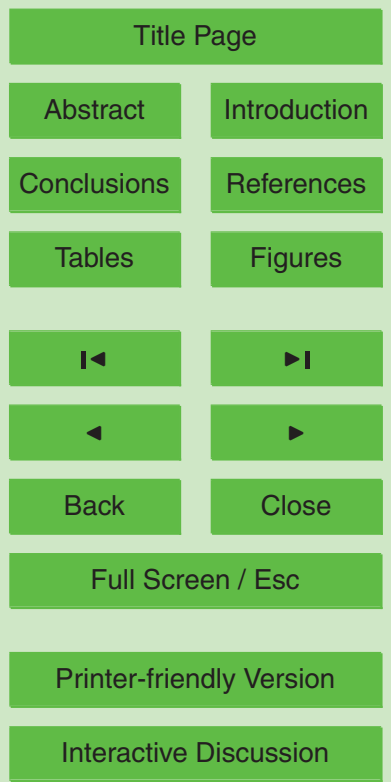


$K=$ effective hydraulic conductivity

$S_{f}=$ effective suction pressure head at the wetting front

HESSD

$\theta_{s}=$ saturated soil moisture content

$\theta_{i}=$ initial soil moisture content

5 For the purpose of infiltration modeling under surface ponding conditions, the above equation can be modified to account for the soil-water pressure head at the surface.

Owing to its simplicity and satisfactory performance for a great variety of infiltration problems, the Green-Ampt Model has been the model of choice for infiltration estimation in many physically-based hydrological models. Main utility of this model approach 10 lies in its estimation of infiltration rate. The actual water content distribution with soil depth cannot be simulated, since the model formulation assumes a sharp wetting front (USEPA, 1998b).

\section{Introduction of infiltration modeling in EPA-SWMM 5.0 storage unit}

Being a 1-dimensional hydraulic model, EPA-SWMM 5.0 simulates the hydrology, hy15 draulics and water quality of a sewerage system network based on the model's interconnected series of (point-scale) sub-catchments, conveyance elements, storage elements and other types of nodes (e.g. weirs, outfalls). As mentioned above, the standard EPA-SWMM model does not provide for modeling of the infiltration process in its storage nodes within the drainage network. On the other hand, the model implements infiltration process in its hydrological element, the sub-catchments. The model offers three choices for modeling of infiltration in catchments (L. A. Rossman, 2007), namely, Horton's Equation, Green-Ampt Method and Curve Number Method. Horton equation and Curve number methods are empirical approaches that are difficult to be modified to simulate a situation with considerable surface ponding (as in the case of infiltration storages). As stated above, Green Ampt method on the other hand is a physically based method and hence allows more flexibility in application. The classical equation shown in Eq. (2) assumes negligible pressure head at the surface due

\section{Incorporating infiltration modelling in urban flood management}

A. S. Jumadar et al.

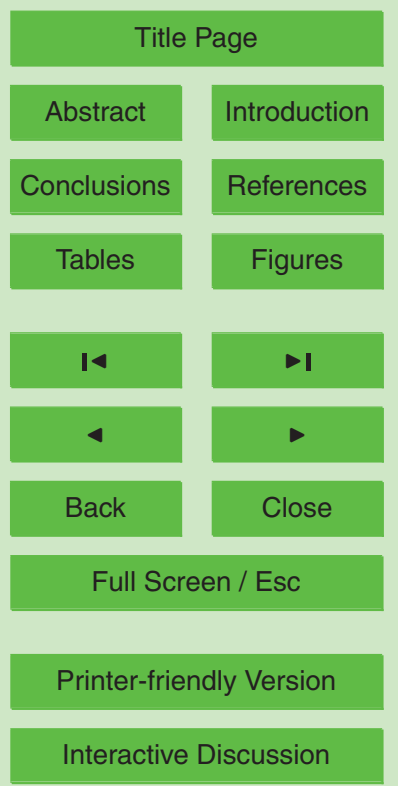


to ponding, which is a reasonable assumption for hilly catchment surfaces (USEPA, 1998a). However, this assumption is a drawback with respect to infiltration processes in storage unit; hence a different variation of the equation can be derived to account for the surface ponding pressure head, giving the following relationship:

${ }_{5} f=\frac{d F}{d t}=-K_{s}\left[1+\frac{\left(\theta_{s}-\theta_{i}\right)\left(S_{f}-h_{s}\right)}{F}\right]$

where $h_{s}$ is the soil-water pressure head at the surface, and is assumed to be equal to the depth of ponded water on the soil surface.

\subsection{Modification of EPA-SWMM 5.0 model code - the technique}

Infiltration models in EPA-SWMM are currently being called into action in the sub10 catchments during runoff computation. The sub-catchments are treated as non linear reservoirs whose inflow comes from precipitation and any designated up-stream subcatchments. The outflows from the sub-catchments include infiltration, evaporation and surface runoff as illustrated in Fig. 1. A similar analogy was applied in this research for introducing infiltration modeling in the storage unit. Only simple modifications are 15 needed to introduce infiltration loss into the storage compartment, for all the computation routines are already available as they are used in the original model for calculating infiltration loss in sub-catchments.

EPA SWMM 5.0 model provides an easy to use graphical user interface that had contributed immensely to the model's popularity among practitioners. We therefore aimed at implementation of the aforementioned modifications in a mode that is fully compatible with and operatable from the graphical user interface as this would help the user to readily adapt the new model. The most challenging aspect of this requirement is the reprogramming of the graphical user interface to allow the user to input infiltration parameters (e.g. Green Ampt soil parameters, groundwater level, etc.). We overcame this challenge by taking advantage of the fact that the subcatchment object has all these input facilities already implemented and introduced the so-called "fake" subcatchments

HESSD

5, 1533-1566, 2008

\section{Incorporating infiltration modelling in urban flood management}

A. S. Jumadar et al.

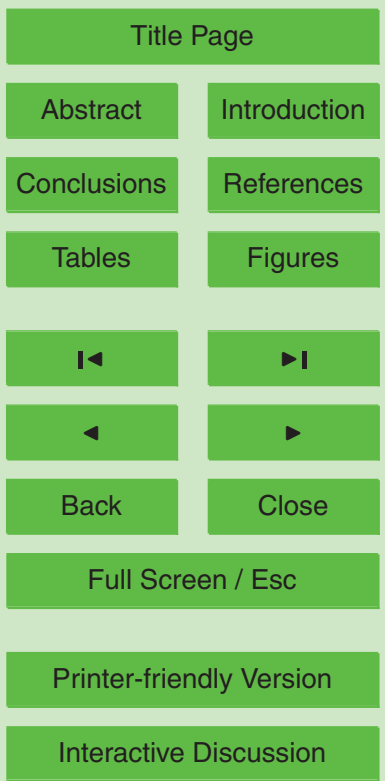

Interactive Discussion 
in the model domain. A "fake" subcatchment is not connected to the drainage system that is being modelled, but at the same time exists in the modeling domain. It is used only as a carrier of data from user interface to the computation engine. While the computation engine will also compute flow quantities for these fake subcatchments, it does 5 not alter the results of the drainage network, as the fakes are not physically linked to the drainage system. Figure 3, clarifies this concept: The original drainage system comprise of subcatchment $\mathrm{C} 1$, conveyers $\mathrm{S} 1$ and $\mathrm{S} 2$, node $\mathrm{J} 1$, storage $\mathrm{J} 2$ and outfall J3. J2FS is a fake subcatchment that is used to specify infiltration data for J2 storage unit. Since J2FS is linked to outfall FO, which is not a part of the drainage network, it does not affect the computational results, but only acts as a "carrier" of data for $\mathrm{J} 2$.

During model simulation, the infiltration function is called within the storage unit, during flow routing, to compute the infiltration rate based on those parameters and the storage node water depth at every time step. Based on that infiltration rate, an infiltration volume loss at each flow routing time step is then computed and deducted 15 from the storage inflow before the storage outflow is determined. The changes made in the storage node are also accounted for during the flow routing process, as well as in the mass balance check during routing.

\section{Validation of modified Green-Ampt model in EPA-SWMM 5.0}

The modified Green-Ampt model in EPA-SWMM 5.0 was validated by comparison of 20 based on Richard's equation (Simunek et al, 2008). A two hour infiltration simulation based on Richard's equation (Simunek et al., 2008). A two hour infiltration simulation was conducted for a storage area of $1000 \mathrm{~m}^{2}$.

Modelling in EPA-SWMM involved setting up of the $1000 \mathrm{~m}^{2}$ storage with an initial ponded depth of $1 \mathrm{~m}$. Its corresponding fake sub-catchment was also introduced for the purpose of infiltration modeling in the storage. A dynamic flow routing of the model was then undertaken, with rainfall ignored so as to have no flow into the storage, but only infiltration simulation running in the storage. The storage outflow link

HESSD

$5,1533-1566,2008$

Incorporating

infiltration modelling in urban flood management

A. S. Jumadar et al.

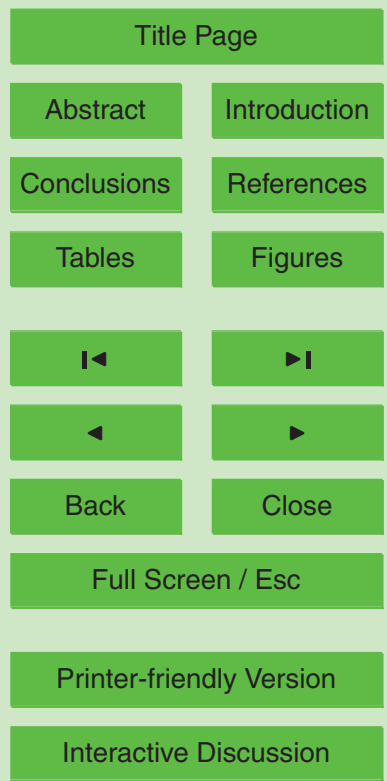

1539 
was set at a negative slope, ensuring no flow out of the storage. Model simulation was then done at 10 min intervals for $2 \mathrm{~h}$ duration, with the volume infiltrated reported at each time interval. Sand soil infiltration parameters were adopted in the fake sub-catchment as: Suction Head $=49 \mathrm{~mm}$, Hydraulic Conductivity $=235.62 \mathrm{~mm} / \mathrm{h}$, Initial 5 moisture deficit $=\theta_{s}-\theta_{i}=0.437-0.045=0.392$.

In the Hydrus 1-D model set-up, a $300 \mathrm{~cm}$ depth sand soil was modeled with $2 \mathrm{~h}$ simulation period adopted as previously in modified Green-Ampt simulation in EPASWMM 5.0. The soil infiltration parameters used are similar to those used in earlier simulation. Upper boundary condition involved a variable pressure head equivalent to 10 water depth variation at the surface from earlier simulation in EPA-SWMM, with free drainage lower boundary condition as simulated in EPA-SWMM 5.0.

The cumulative infiltration values based on the two model results were plotted as indicated in Fig. 2. Based on the comparatively similar cumulative infiltration observations in the storage, as simulated by use of both the modified Green-Ampt model in

EPA-SWMM 5.0, and Hydrus one-dimensional model based on Richard's equation, we can confirm the satisfactory performance of the modified Green-Ampt model.

\section{Effect of infiltration modelling in modified EPA-SWMM 5.0 storage unit}

In order to evaluate the performance of the modifications made in EPA-SWMM on a storm water drainage network, a simple hypothetical cacthment was considered for the 20 purpose of investigating the effect of infiltration processes in the detention storage.

The hypothetical catchment C1, of 100 hectare was modeled, draining to a $2000 \mathrm{~m}^{3}$ capacity storage unit J2, before discharging at outfall J3. A fake sub-catchment J2FS, with infiltration parameters corresponding to those within the detention storage, was also introduced for the purpose of simulating infiltration in the storage node (see Fig. 3)

Hydrodynamic simulations were performed using a $2 \mathrm{~h}$ rainfall event with 10 minute time steps. The infiltration parameters in the fake sub-catchment are varied in each simulation in order to simulate different soil conditions in the storage unit. Figure 4
HESSD

5, 1533-1566, 2008

Incorporating

infiltration modelling

in urban flood

management

A. S. Jumadar et al.

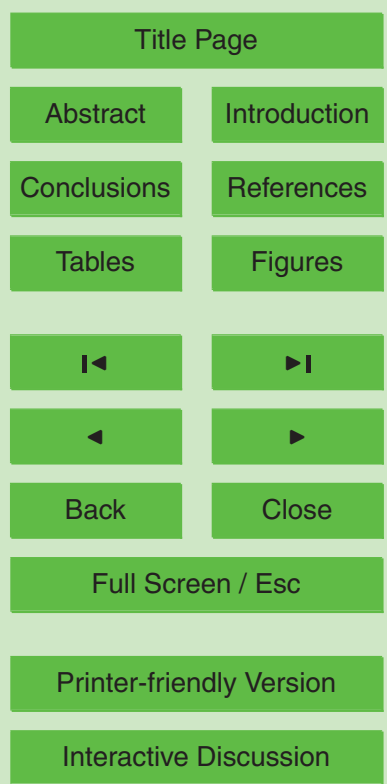


indicates the outflow hydrographs for different infiltration modeling scenarios within the storage unit $\mathrm{J} 2$, based on soil infiltration parameters adopted in the unit.

In terms of flow attenuation, a reduction in both the storage outflow volume and peak was observed, as the adopted soil hydraulic conductivity during infiltration modelling in 5 the storage increases.

\section{Evaluation of catchment scale impact of source and regional control systems}

Two case study areas were considered and modeled under proposed scenarios of source and regional control systems, before their catchment scale impact are evaluated and compared.

10 For the purpose of evaluating the catchments scale impact of source control storage, a $600 \mathrm{~m}^{2}$ lot is adopted with on-site storage. Considering the size of the catchments involved and the modelling details of the building lot level storages, up-scaling of the lot storages effect at sub-catchment level is undertaken. The depression storage depth on impervious area of the catchments was determined to be a viable parameter for depicting the volume of runoff retained at the lot level storages.

\subsection{Case study area I: Sub-basin A of Arroio da Areia basin in Porto Alegre (Southern Brazil)}

Arroio da Areia basin is located in the north of Porto Alegre city in southern Brazil. It is a highly urbanized basin with a drainage area of 1170 hectares (Gersonius, 2005). Urban flooding in the basin is a major problem, which led to a study by the state university that recommended the introduction of detention basins within the catchment conventional drainage network (TUCCI, 2002).

For the purpose of this research study, only a part of the basin denoted as sub-basin A was considered, as illustrated in Fig. 5 showing the macro-drainage layout within the sub-basin.

HESSD

$5,1533-1566,2008$

Incorporating infiltration modelling in urban flood management

A. S. Jumadar et al.

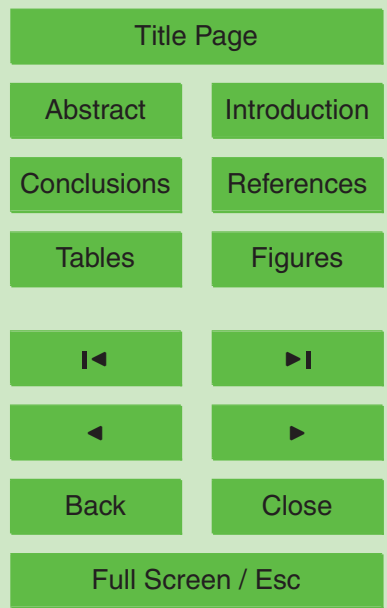

Printer-friendly Version

Interactive Discussion 
The sub-basin A was modeled, with a design storm event of $2 \mathrm{~h}$ duration with 5 year return period $(5 \mathrm{y} 2 \mathrm{~h})$ used for hydrological simulation. A hypothetical case was considered within the 237 hectares sub-basin where six storage option scenarios were modelled, with the physical and urbanisation characteristics of the adopted basin closely 5 following those of the actual basin used earlier in the application of the modified EPASWMM model. The modelled storage scenarios at Sub-basin A include:

1. Source control storage at building lot level within subcatchment's of dimensions (capacity):

$-6.0 \mathrm{~m} \times 3.0 \mathrm{~m} \times 0.5 \mathrm{~m}\left(9 \mathrm{~m}^{3}\right)$

$-3.5 \mathrm{~m} \times 4.0 \mathrm{~m} \times 0.5 \mathrm{~m}\left(7 \mathrm{~m}^{3}\right)$

$-3.0 \mathrm{~m} \times 3.0 \mathrm{~m} \times 0.50 \mathrm{~m}\left(4.5 \mathrm{~m}^{3}\right)$

2. Regional storages at subcatchment's level with capacity equal to:

- sum of $9 \mathrm{~m}^{3}$ source control storage at building lot level in subcatchment

- sum of $7 \mathrm{~m}^{3}$ source control storage at building lot level in subcatchment

- sum of $4.5 \mathrm{~m}^{3}$ source control storage at building lot level in subcatchment

\subsubsection{Modelling of source control storages}

For the source control scenarios, as mentioned in the introduction above, up-scaling of the lot storages at sub-catchment level is undertaken.

The steps involved in the up-scaling process entailed:
1. Modelling of source control storages at building lot level, to determine the volume of flow retained at the lot level. A $600 \mathrm{~m}^{2}$ building lot was adopted with physical dimensions as indicated in Fig. 6. The percentage of impervious area of lot was determined as 50.67 , with overland flow width of $16 \mathrm{~m}$ adopted. The volume of runoff leaving the lot is noted as well as the volume of storm water retained at the
HESSD

5, 1533-1566, 2008

Incorporating infiltration modelling in urban flood management

A. S. Jumadar et al.

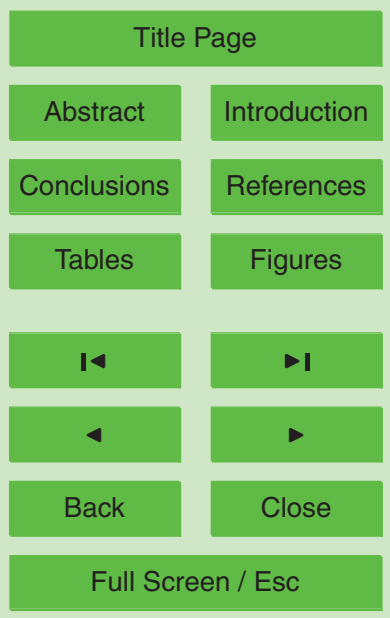

Printer-friendly Version

Interactive Discussion 
lot storage. The latter volume retained at the lot is the sum of volume infiltrated at lot storage as well as the final stored volume at the end of simulation.

HESSD

2. Determination of the population within the subcatchments, based on specified population densities. This was followed by computation of the number of lots at the subcatchments, based on the number of occupants.

3. Computation of the sum of flow retained at lots of each subcatchment. $\Sigma$ (volume of flow retained at subcatchment $)=$ No. of lots $\times$ Volume retained at lot

4. Computation of equivalent depression storage depth on impervious area of subcatchment that will depict the volume of flow retained at lot level within respective subcatchment's. Depression storage depth $=[\Sigma$ (volume of flow retained at subcatchment)]/Subcatchment impervious area

Table 1 illustrates the parameterization of $6.0 \times 3.0 \times 0.5 \mathrm{~m}^{3}$ lot storage on sub-basin A sub-catchments as discussed above. Model set-up of source control storage scenarios involved depiction of volume of flow retained at lot level by the equivalent depression storage depth on respective subcatchments.

\subsubsection{Modelling of regional storages}

Regional storages were modelled at subcatchments level within sub-basin A as indicated in Fig. 7, showing model set-up for regional systems. The capacity of the regional storages represents the sum of source control storages at building lot level within the respective subcatchments.

\subsubsection{Model simulation results}

From Table 2 as well as the outflow runoff hydrographs for proposed storage options in Figs. 8, 9 and 10, it is observed that source control options do have a greater influence in flow attenuation compared to respective regional capacity systems, both in terms of

\section{Incorporating infiltration modelling in urban flood management}

A. S. Jumadar et al.

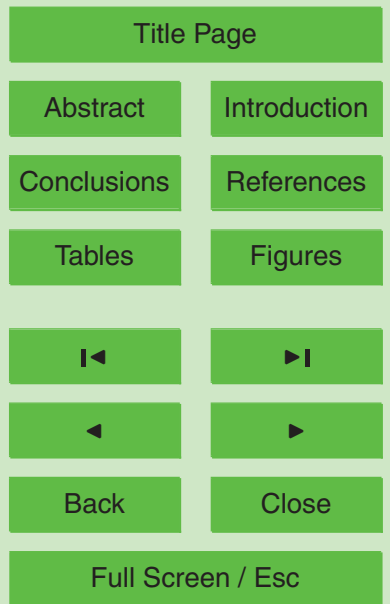

Printer-friendly Version

Interactive Discussion 
reduction in runoff volume and peak. The same can be said with respect to surface flooding reduction in sub-basin A. However, for the $4.5 \mathrm{~m}^{3}$ source control scenario, the observed difference in performance, compared to its respective regional storage, is minimal.

$5 \quad$ Lag time, which is the time of the peak of the outflow measured from the centroid of the rainfall, has been used as a key measure of attenuation of flows. From Table 2, we also observe that significant lag times were registered for the bigger storage options compared to the smaller ones as expected.

From on-site monitoring studies conducted in Scotland, it was observed that source 10 control systems had a greater influence in flow attenuation than site and regional control systems (Jefferies, 2003). However, from the results of this study, if we were to compare between respective source control and regional options, we note that in the case of source control storages of $7 \mathrm{~m}^{3}$ and $4.5 \mathrm{~m}^{3}$ capacities, they show no significant difference in lag time compared to their respective regional storages. In the case of the $9 \mathrm{~m}^{3}$ source control storage, we notice that the observed lag time of $34 \mathrm{~min}$ is smaller compared to its respective regional storages, whose lag time is $44 \mathrm{~min}$. This is contrary to the observations made in the Scottish study; however this could be seen as a set-back of the up-scaling effect of source control systems at catchment level, using the depression storage parameter of the catchment.

However, considering their performance with respect to reduction in outflow volume and peak outflow rate, the source control option does perform better.
HESSD

5, 1533-1566, 2008

Incorporating

infiltration modelling in urban flood management

A. S. Jumadar et al.

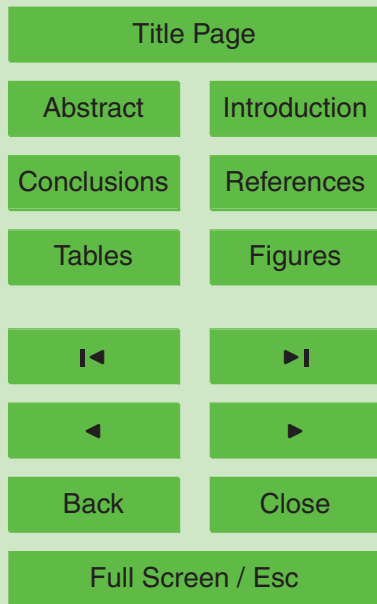

Printer-friendly Version

Interactive Discussion 
Aimata catchment is found within Okutune basin, situated in Gumma prefecture in Kanto region of Japan. Its drainage area covers $111 \mathrm{~km}^{2}$ of a hilly terrain, currently un-inhabited in its pristine state. The main river channel of the catchment is $19 \mathrm{~km}$

5 long. Kanto loam is the native soil, characterized by high water content (I. Kaihotsu and T. Tanaka, 1982).

The objective of our study in this case area was to determine the best storage options to be recommended in a developed catchment of a future hypothetical scenario, where we make an assumption that the catchment will have developed to a sub-urban 10 area. It should be noted that the geographical location of this catchment does not make it possible for future urbanization. Furthermore, this is a catchment that is a feed area of an important reservoir and is protected. However, the availability of good quality rainfall runoff history and the fact that the catchment at present is in a pristine condition, renders this case study well for our modeling purpose. Our objective in modeling this basin was to investigate the ability of different storage options to return the flow regime of an urbanized situation to its undisturbed pristine conditions. First we calibrated and validated the model based on several rainfall events and their runoff data measured on the catchment. The proposed storage options are then modeled in the developed catchment scenario, before an evaluation of their hydraulic performance within the catchment is undertaken.

Calibrated catchment parameters included, width of overland flow determined as $9000 \mathrm{~m}$, with an average surface slope of $12 \%$. Calibrated Green-Ampt infiltration parameters for the Kanto loam soil on site were also identified, with soil capillary suction head of $210 \mathrm{~mm}$, saturated soil hydraulic conductivity of $1.016 \mathrm{~mm} / \mathrm{h}$ and initial soil moisture deficit of 0.2 .

\section{Incorporating infiltration modelling in urban flood management}

A. S. Jumadar et al.

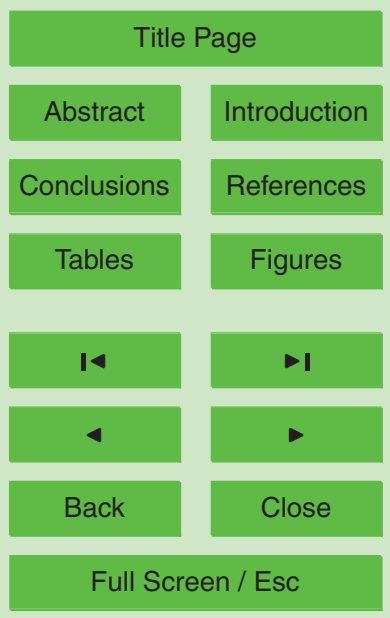

Printer-friendly Version

Interactive Discussion 


\subsubsection{Modelling of proposed storage options}

The catchment was then modeled, in the modified EPA-SWMM 5.0, with two scenarios considered:

- Pristine state with $0 \%$ impervious area on catchment

- Future developed state where the catchment area has developed to a sub-urban area with average population density of 22 inhabitants/hectare, based on half the density value for urban areas in Japan (Cox, 2007). The percentage of impervious area on catchment, based on the earlier developed building lot of $600 \mathrm{~m}^{2}$ is $22.3 \%$.

Under the developed state, 3 scenarios are modeled based on the following proposed storage options, with the view of determining the best option to reduce peak outflows to a level similar to pristine state peak outflow regime:

- Source control lot storage provision on catchment that achieves pristine peak ouflow rate

- Regional storage that achieves pristine peak ouflow rate

- Regional storage whose capacity is equivalent to sum of lot storage capacity that achieves pristine peak outflow rate (modeled for the purpose of comparison of flow attenuation response).

For modeling of source control storage on catchment, as illustrated earlier in the Arroio da Areia basin case, the depression storage depth of impervious area on catch-

\section{HESSD}

$5,1533-1566,2008$

Incorporating

infiltration modelling in urban flood management

A. S. Jumadar et al.

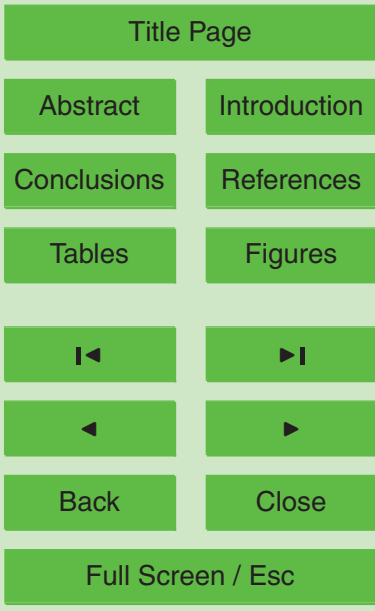

Printer-friendly Version

Interactive Discussion 
In the future developed catchment scenario, as illustrated in Fig. 12, the peak outflow in the catchment increases from the pristine value of $420 \mathrm{~m}^{3} / \mathrm{s}$ to $509.6 \mathrm{~m}^{3} / \mathrm{s}$. Upon modelling of proposed storage options in the future scenario, the storage capacity re-

5 quirements, for source control systems at building lot level and regional systems, to restore pristine peak outflow rate of $420 \mathrm{~m}^{3} / \mathrm{s}$ are:

$-6 m^{3}$ source control storage capacity at building lot level

- 140 hectare $\times 1 \mathrm{~m}$ depth regional storage whose capacity is equivalent to $17.2 \mathrm{~m}^{3}$ lot capacity recommendation

10 An interesting observation form the result, as indicated in Figs. 12 and 13 is that the $6 \mathrm{~m}^{3}$ source control option mimics the pristine catchment conditions in terms of the observed runoff hydrograph, better than the regional storages. For the purpose of comparison, we also note that the regional system of 50 hectare $\times 1 \mathrm{~m}$ depth, whose capacity is equivalent to $6 \mathrm{~m}^{3}$ building lot storage at catchment, performs poorly in 15 terms of reduction in both peak runoff rate and volume as illustrated in Table 4 and Fig. 13.

\section{Conclusions}

The two main objectives of the study focused on introduction and assessment of the effect of infiltration modeling in detention storage within the urban storm water model EPA-SWMM 5.0, and the evaluation and comparison of catchment scale impact of source and regional control storage systems. A review of the three infiltration models adopted in EPA-SWMM 5.0 showed that only the Green-Ampt model could be modified to make it suitable for infiltration modelling under surface ponding conditions experienced in detention storage systems.

\section{Incorporating infiltration modelling in urban flood management}

A. S. Jumadar et al.

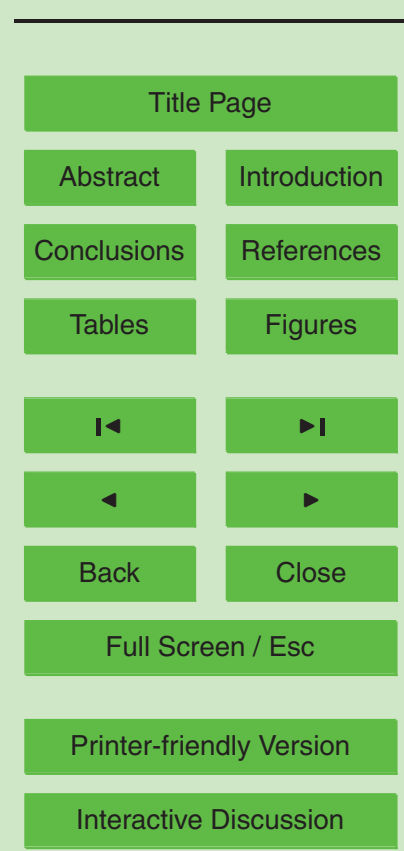


The performance of the modified Green-Ampt model in EPA-SWMM 5.0 with respect to infiltration simulation in the storage unit was found to be satisfactory upon its validation with the Hydrus 1D, physically based infiltration model based on Richard's equation. The modified software works within the original graphical user interface of 5 SWMM 5. 0 model, providing a convenient way for the practitioners to undertake infiltration modelling for SUDS design. The modified model code is available in free and open source form.

By introduction of infiltration modelling in the storage unit in EPA-SWMM 5.0, the flow attenuation performance of the unit was improved as demonstrated in the hypothetical 10 catchment case, where the model was applied on.

Evaluation of catchment scale impact of source control storage systems at building lot level was made possible by use of the depression storage depth parameter of the catchment to up-scale the effect of lot storages at catchment level. The adopted approach was satisfactory in depicting the catchment scale impact of on-site storages systems adopted in the study. However, it was observed that for the on-site storage in Arroio da Areia basin case in Brazil, a setback of the approach with respect to depiction of lag time at catchment level was noted.

Based on the results of the two case study area catchments in Southern Brazil and Japan, we conclude that source control storage options have a greater impact a catchment level, with respect to flow attenuation, both in terms of runoff volume and peak, compared to regional systems whose capacity is equivalent to the sum of lot control storage capacity at the catchment.

An interesting observation made from Aimata case study is that the source control option, providing storage at each household lot level, can mimic the pristine catchment conditions in the hydrograph better than the regional storages. This indicates a possibility that the source control options are more effective in restoring natural balance in the water cycle, lost during urbanization.

\section{HESSD}

5, 1533-1566, 2008

\section{Incorporating infiltration modelling in urban flood management}

A. S. Jumadar et al.

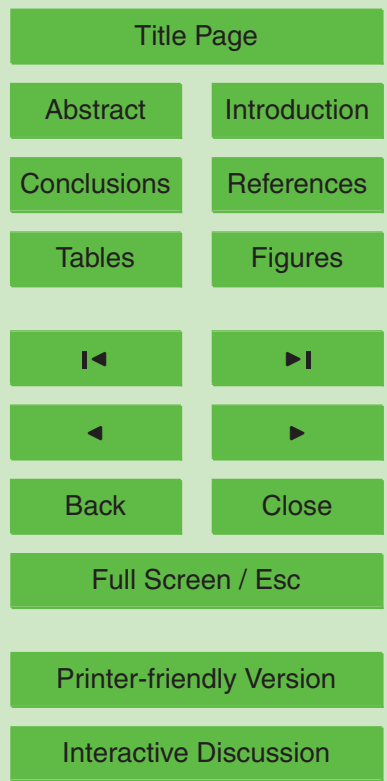




\section{References}

Cox, W.: Demographia World Urban Areas (World Agglomerations), Illinois, USA, Wendel Cox Consultancy, 2007.

Elliott, A. H. and Trowsdale, S. A.: A review of models for low impact urban stormwater drainage, Environ. Modell. Softw., 22, 394-405, 2006.

Gersonius, B.: Towards Sustainable Planning and Design of Stormwater Control Solutions in Brazil, Civil Engineering, Delft, Delft University of Technology, 2005.

Kaihotsu, I. and Tanaka, T.: Machanism of vertical water movement in Kanto Loam during and after rainfall, Ibaraki, Japan, 1982.

10 Jefferies, C.: SUDS in Scotland - The Monitoring Programme of the Scottish Universities SUDS Monitoring Group, Environment Agency, Sepa and Sniffer, 2003.

Rossman, L. A.: Storm Water Management Model - User's Manual Version 5.0. Ohio, USA, United States Environmental Protection Agency, 2007.

Wallis, S. G., Morgan, C. T., and Heal, K.: Modelling the Hydrological Performance of Reten15 tion Ponds as a Sustainable Catchment Management Tool, Geophys. Res. Abstr., 5, 14060, 2003.

Šimunek, J., van Genuchten, M. Th., and Šejna, M.: Development and applications of the HYDRUS and STANMOD software packages, and related codes, Vadose Zone Journal, doi:10.2136/VZJ2007.0077, Special Issue "Vadose Zone Modeling", 7(2), 587-600, 2008.

Tourbier, J. T. and White, I.: Sustainable Measures for Flood Attenuation: Sustainable Drainage and Conveyance Systems (SUDACS), in: Advances in Urban Flood Management, edited by: Zevenbergen, C., Ashley, R., Garvin, S., and Pasche, E., Bakelma, 2007.

Tucci, C. E. M.: Plano Director De Drenagem Urbana, Volume IV, Institute of Hydraulical Research Federal, University of the Rio Grande Do Sul, 2002.

USEPA: Estimation of Infiltration Rate in the Vadose Zone: Application of Selected Mathematical models, Volume II, 1998a.

USEPA: Estimation of Infiltration Rate in the Vadose Zone: Compilation of Simple Mathematical models, Vol. I, United States Environmental protection Agency, 1998b.
HESSD

5, 1533-1566, 2008

Incorporating

infiltration modelling

in urban flood

management

A. S. Jumadar et al.

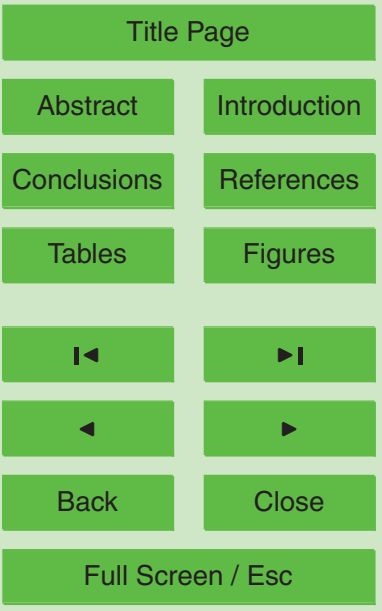

Printer-friendly Version

Interactive Discussion 


\section{HESSD}

$5,1533-1566,2008$

Table 1. Parameterization of $6.0 \times 3.0 \times 0.5 \mathrm{~m}^{3}$ lot storage on sub-basin A sub-catchments.

Arroio da Areia Basin: $9 \mathrm{~m}^{3}$ source control storage capacity parameterisation $(6.0 \mathrm{~m} \times 3.0 \mathrm{~m} \times 0.5 \mathrm{~m})$

\begin{tabular}{|c|c|c|c|c|c|c|c|c|c|}
\hline Subcatchment & Area (ha) & $\begin{array}{l}\text { Current Pop. } \\
\text { Density } \\
\text { (inhab./ha) }\end{array}$ & $\begin{array}{l}\text { Population } \\
\text { (inhab) }\end{array}$ & No of lots & $\begin{array}{l}\text { Impervious } \\
\text { area (\%) }\end{array}$ & $\begin{array}{l}\text { Impervious area } \\
\text { at } \\
\text { subcatchment } \\
\text { (ha) }\end{array}$ & $\begin{array}{l}\text { Sum of stored } \\
\text { and infiltrated } \\
\text { volume retained } \\
\text { in lots }\left(\mathrm{m}^{3}\right)\end{array}$ & $\begin{array}{l}\text { Equivalent impery } \\
\text { area dep. Storage } \\
\text { depth on subcatch- } \\
\text { ment retaining the } \\
\text { Sum of Volume } \\
\text { stored and infiltrated } \\
\text { at lots }(\mathrm{mm})\end{array}$ & $\begin{array}{l}\text { Equivalent } \\
\text { Regional capacity } \\
\text { at subcatchment } \\
\left(\mathrm{m}^{3}\right)\end{array}$ \\
\hline Ala & 27885 & 46.00 & 1283 & 257 & 29.24 & 8.154 & 3287.07 & 40.31 & 2309 \\
\hline Alb & 5577 & 46.00 & 257 & 51 & 29.24 & 1.631 & 657.41 & 40.31 & 462 \\
\hline A2a & 80427 & 72.47 & 5829 & 971 & 40.80 & 32.814 & 12446.86 & 37.93 & 8743 \\
\hline $\mathrm{A} 2 \mathrm{~b}$ & 11144 & 72.47 & 808 & 135 & 40.80 & 4.547 & 1724.64 & 37.93 & 1211 \\
\hline A2c & 5330 & 72.47 & 386 & 64 & 40.80 & 2.175 & 82487 & 37.93 & 579 \\
\hline АЗа & 38025 & 51.62 & 1963 & 393 & 32.17 & 12.233 & 5030.00 & 41.12 & 3533 \\
\hline A3b & 12675 & 51.62 & 654 & 131 & 32.17 & 4.078 & 1676.67 & 41.12 & 1178 \\
\hline A4a & 13500 & 39.19 & 529 & 106 & 25.17 & 3.398 & 1355.78 & 39.90 & 952 \\
\hline A4b & 7500 & 39.19 & 294 & 59 & 25.17 & 1.888 & 753.21 & 39.90 & 529 \\
\hline A4c & 9000 & 39.19 & 353 & 71 & 25.17 & 2.265 & 903.85 & 39.90 & 635 \\
\hline \multirow[t]{2}{*}{ A5 } & 25500 & 21.57 & 550 & 79 & 10.00 & 2.550 & 1006.80 & 39.48 & 707 \\
\hline & & & & & & $\begin{array}{l}\text { Volume retained } \\
\text { at lots }\end{array}$ & 2966717 & & \\
\hline
\end{tabular}

Incorporating infiltration modelling in urban flood management

A. S. Jumadar et al.

\section{Title Page}

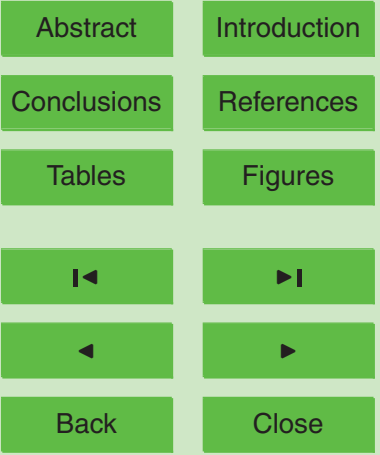

Full Screen / Esc

Printer-friendly Version

Interactive Discussion 


\section{HESSD}

5, 1533-1566, 2008

Table 2. Sub-basin A - Proposed storage options model simulation analysis.

\begin{tabular}{|c|c|c|c|c|c|c|c|}
\hline Proposed storage option & $\begin{array}{l}\text { Lag Time of } \\
\text { outflow } \\
\text { hydrograph } \\
\text { (min) }\end{array}$ & $\begin{array}{l}\text { Surface } \\
\text { flooding } \\
\text { volume } \\
\left(\mathrm{m}^{3}\right)\end{array}$ & $\begin{array}{l}\text { peak outflow } \\
\text { rate }\left(\mathrm{m}^{3} / \mathrm{s}\right)\end{array}$ & $\begin{array}{l}\text { external outflow } \\
\text { volume }(\mathrm{ml})\end{array}$ & $\begin{array}{l}\% \text { reduction in } \\
\text { surface flooding }\end{array}$ & $\begin{array}{l}\% \text { reduction in } \\
\text { external outflow } \\
\text { volume }\end{array}$ & $\begin{array}{l}\% \text { reduction in } \\
\text { peak ouflow } \\
\text { rate }\end{array}$ \\
\hline No storage provision & 10 & 14.456 & 9.050 & 29.229 & & & \\
\hline $\begin{array}{l}\text { source control } 9 \mathrm{~m}^{3} \\
(6 \times 3 \times 0.5)\end{array}$ & 31 & 0.130 & 3.303 & 13.894 & 99.1 & 52.5 & 53.1 \\
\hline $\begin{array}{l}\text { regional (eqv_9 } \mathrm{m}^{3} \\
\text { source control cap.) }\end{array}$ & 44 & 0.383 & 3.944 & 14.959 & 99.4 & 48.8 & 44.1 \\
\hline $\begin{array}{l}\text { source control } 9 \mathrm{~m}^{3} \\
(3.5 \times 4 \times 0.5)\end{array}$ & 34 & 2.995 & 4.940 & 19.644 & 80.8 & 39.6 & 32.8 \\
\hline $\begin{array}{l}\text { regional (eqv_9 } \mathrm{m}^{3} \\
\text { source control cap.) }\end{array}$ & 33 & 2.852 & 5.242 & 19.011 & 80.3 & 35.0 & 25.6 \\
\hline $\begin{array}{l}\text { source control } 4.5 \mathrm{~m}^{3} \\
(3 \times 3 \times 0.5)\end{array}$ & 23 & 6.910 & 6.080 & 21.699 & 52.2 & 25.8 & 13.8 \\
\hline $\begin{array}{l}\text { regional (eqv_ } 4.5 \mathrm{~m}^{3} \\
\text { source control cap.) }\end{array}$ & 23 & 9.468 & 6.080 & 22.129 & 48.3 & 24.3 & 13.8 \\
\hline
\end{tabular}

Incorporating infiltration modelling in urban flood management

A. S. Jumadar et al.

Title Page

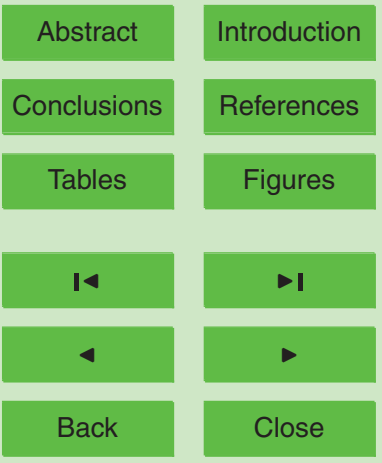

Full Screen / Esc

Printer-friendly Version

Interactive Discussion 


\section{HESSD}

5, 1533-1566, 2008

\section{Incorporating infiltration modelling in urban flood management}

Table 3. Parameterization of $6 \mathrm{~m}^{3}$ lot storage on Aimata catchment.

\begin{tabular}{|c|c|c|c|c|c|c|c|c|}
\hline \multicolumn{9}{|c|}{ Aimata catchment $7 \times 3.5 \times 0.25\left(6.125 \mathrm{~m}^{3}\right)$ lot storage parameterisation $\left(Q_{\text {peak }}=Q_{\text {pre-urb }}\right)$} \\
\hline Area (ha) & $\begin{array}{l}\text { Future Pop. } \\
\text { Density in } \\
\text { catchment } \\
\text { (inhab./ha) }\end{array}$ & $\begin{array}{l}\text { Future } \\
\text { Population } \\
\text { in catchment } \\
\text { (inhabitants) }\end{array}$ & No. of lots & $\begin{array}{l}\text { Impervious } \\
\text { area (\%) }\end{array}$ & $\begin{array}{l}\text { Impervious } \\
\text { area at } \\
\text { catchment } \\
\text { (ha) }\end{array}$ & $\begin{array}{l}\text { Sum of stored } \\
\text { and infiltrated } \\
\text { volume retained } \\
\text { at lots }\left(\mathrm{m}^{3}\right)\end{array}$ & $\begin{array}{l}\text { Equivalent } \\
\text { impery area } \\
\text { dep. Storage } \\
\text { depth on } \\
\text { catchment } \\
\text { retaining the } \\
\text { Sum of Volume } \\
\text { stored and } \\
\text { infiltrated at lots } \\
(\mathrm{mm})\end{array}$ & $\begin{array}{l}\text { Equivalent Re- } \\
\text { gional Storage } \\
\text { capacity at } \\
\text { catchment }\left(\mathrm{m}^{3}\right)\end{array}$ \\
\hline 11113 & 22.00 & 244486 & 81495 & 22.30 & 2478.169 & 3492890 & 140.95 & 499159 \\
\hline
\end{tabular}

A. S. Jumadar et al.

Title Page

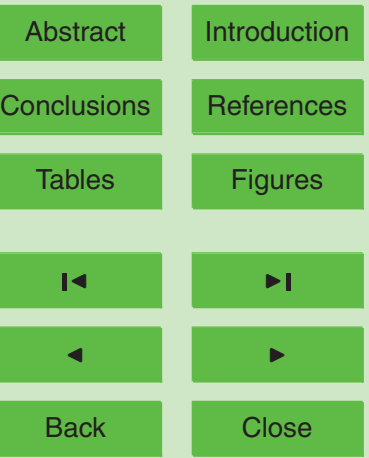

Full Screen / Esc

Printer-friendly Version

Interactive Discussion 


\section{HESSD}

$5,1533-1566,2008$

Table 4. Flow attenuation analysis for proposed storage options in Aimata catchment.

\begin{tabular}{lllll}
\hline Scenario & $\begin{array}{l}\text { External Outflow } \\
\text { Volume }(\mathrm{ml})\end{array}$ & $\begin{array}{l}\text { Peak Outflow } \\
\text { Rate }\left(\mathrm{m}^{3} / \mathrm{s}\right)\end{array}$ & $\begin{array}{l}\text { \% Reduction in } \\
\text { External Outflow } \\
\text { Volume }\end{array}$ & $\begin{array}{l}\text { \% Reduction in } \\
\text { Peak Outflow } \\
\text { Rate }\end{array}$ \\
\hline $\begin{array}{l}\text { Pristine Catchment } \\
\text { Developed Catchment: }\end{array}$ & 9944.230 & 419.939 & & 0.0 \\
$\begin{array}{l}\text { no storage provision } \\
\text { Developed Catchment: }\end{array}$ & 11931.950 & 509.596 & 0.0 & 19.6 \\
$\begin{array}{l}\text { Source control storage provided } \\
\text { of } 6.125 \mathrm{~m}^{3} \text { lot capacity }\end{array}$ & 8438.921 & 419.845 & 29.3 & \\
$\begin{array}{l}\left(Q_{\text {peak }}=Q_{\text {pristine }}\right) \\
\text { Developed Catchment: }\end{array}$ & 10051.299 & 498.924 & 15.8 & 6.1 \\
$\begin{array}{l}\text { Regional storage provided of } \\
50 \text { hax } 1 \mathrm{~m} \text { capacity equivalent to } \\
\text { sum of } 6.125 \mathrm{~m}^{3} \text { lot capacity on } \\
\text { catchment }\end{array}$ & & & & \\
$\begin{array}{l}\text { Developed Catchment: Regional } \\
\text { storage provided of } 140 \text { hax } 1 \mathrm{~m} \\
\text { capacity equivalent to sum of }\end{array}$ & 9401.660 & 419.689 & 38.0 & 19.6 \\
$\begin{array}{l}19.2 \mathrm{~m}^{3} \text { lot capacity on catchment } \\
\left(Q_{\text {peak }}=Q_{\text {pristine }}\right)\end{array}$ & & & \\
\hline
\end{tabular}

\section{Incorporating infiltration modelling in urban flood management}

A. S. Jumadar et al.

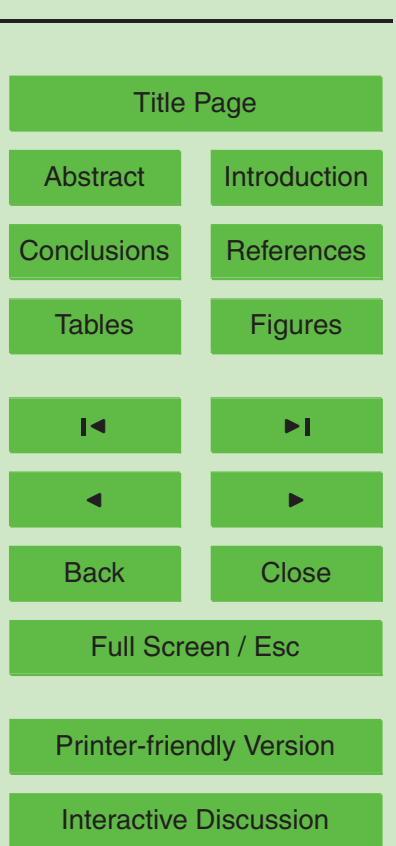




\section{HESSD}

$5,1533-1566,2008$

Rainfall Intensity i

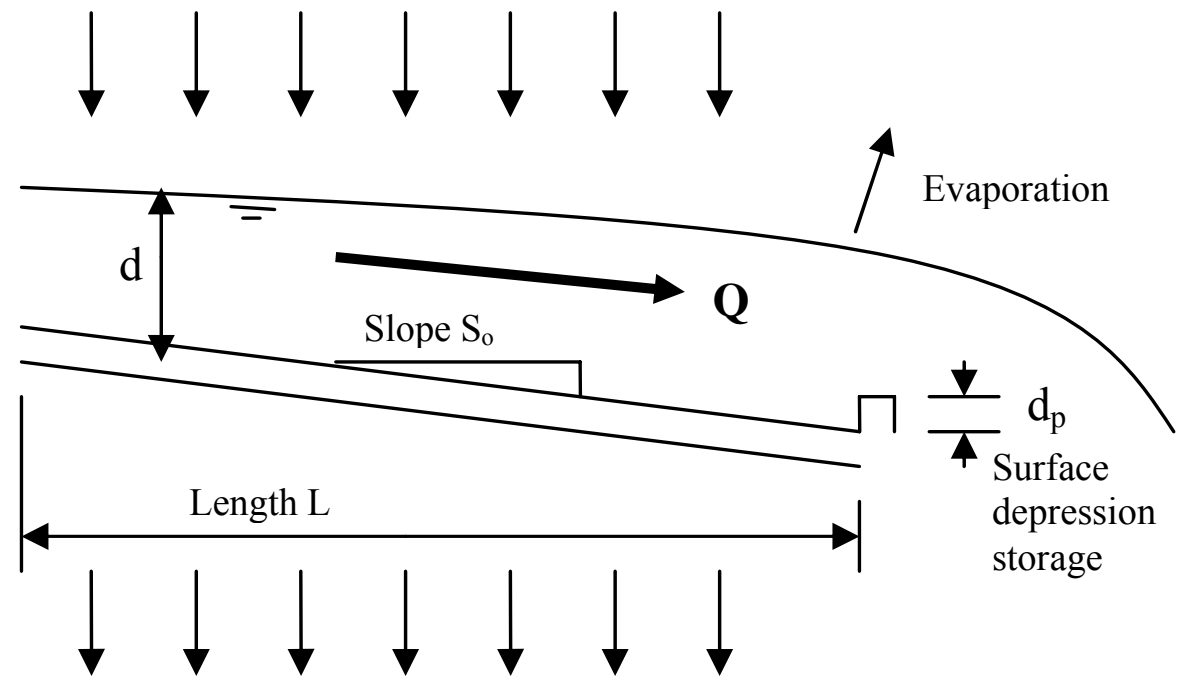

Infiltration Rate $\mathrm{f}$

Fig. 1. Conceptual view of surface runoff computation in EPA-SWMM.
Incorporating infiltration modelling in urban flood management

A. S. Jumadar et al.

Title Page

Abstract

Introduction

Conclusions

References

Tables

Figures

14

$\rightarrow$ I

4

Back

Close

Full Screen / Esc

Printer-friendly Version

Interactive Discussion 


\section{HESSD}

$5,1533-1566,2008$

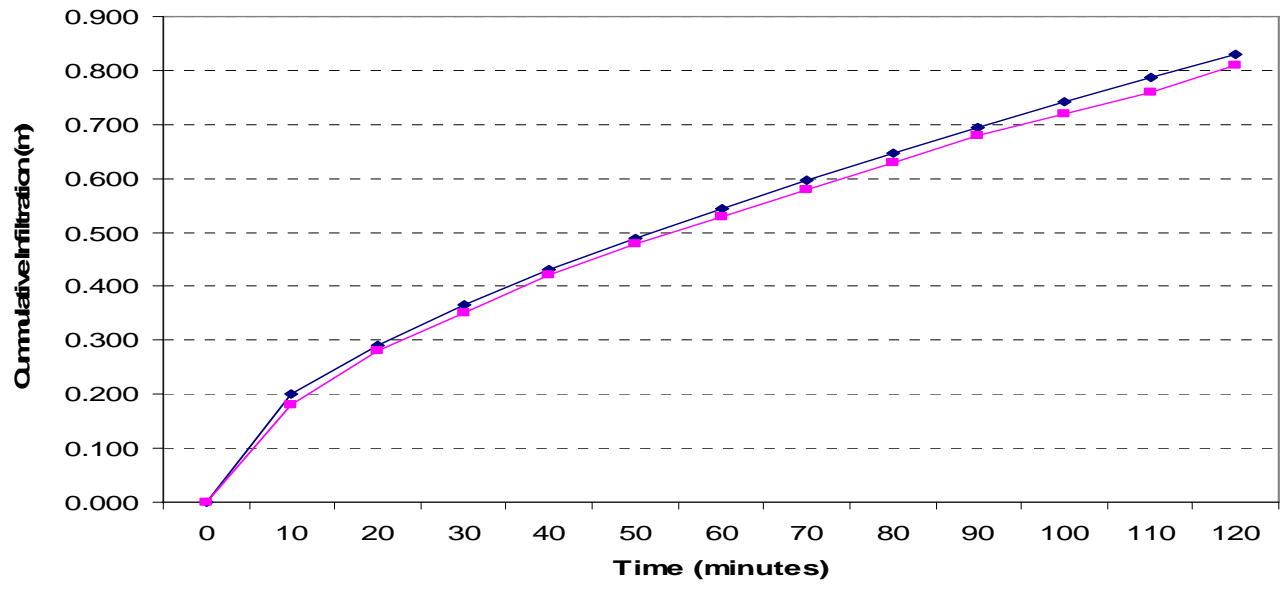

Modified Green Ampt method in EPA-SWMM - - Hydrus 1D (Richard`s equation)

Fig. 2. Validation of modified Green-Ampt model in EPA-SWMM with Hydrus 1-D model.

Incorporating
infiltration modelling
in urban flood
management

A. S. Jumadar et al.

Title Page

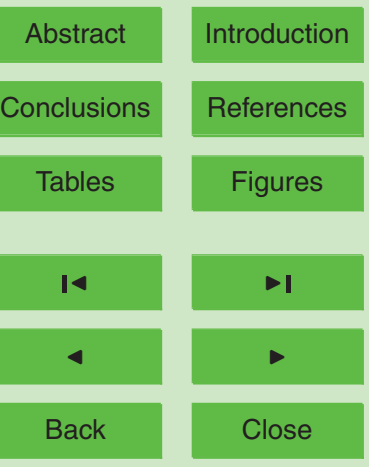

Full Screen / Esc

Printer-friendly Version

Interactive Discussion 


\section{HESSD}

5, 1533-1566, 2008
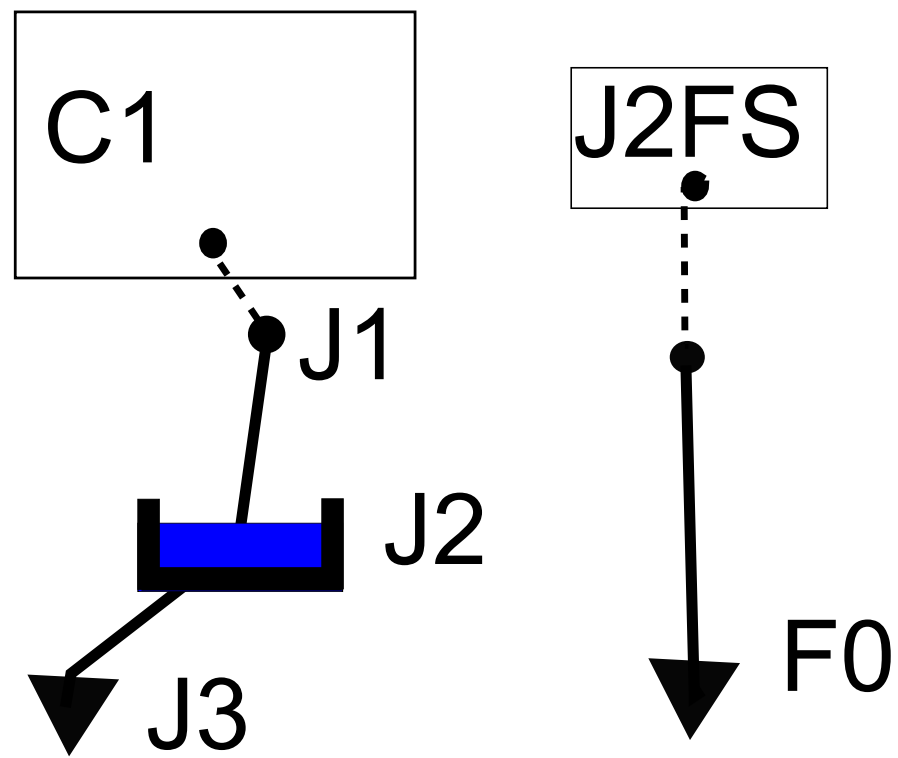

Incorporating infiltration modelling in urban flood management

A. S. Jumadar et al.

Title Page

Abstract

Conclusions

Tables

14

4

Back

Full Screen / Esc

Printer-friendly Version

Fig. 3. Model set up of hypothetical catchment $C 1$ in modified EPA-SWMM 5.0, showing also the fake sub-catchment J2FS, whose infiltration rate is used to compute infiltration loss in storage unit J2. Note that the fake subcatchment is routed to a fake outflow FO that is independent of the network being analyzed. 


\section{HESSD}

$5,1533-1566,2008$

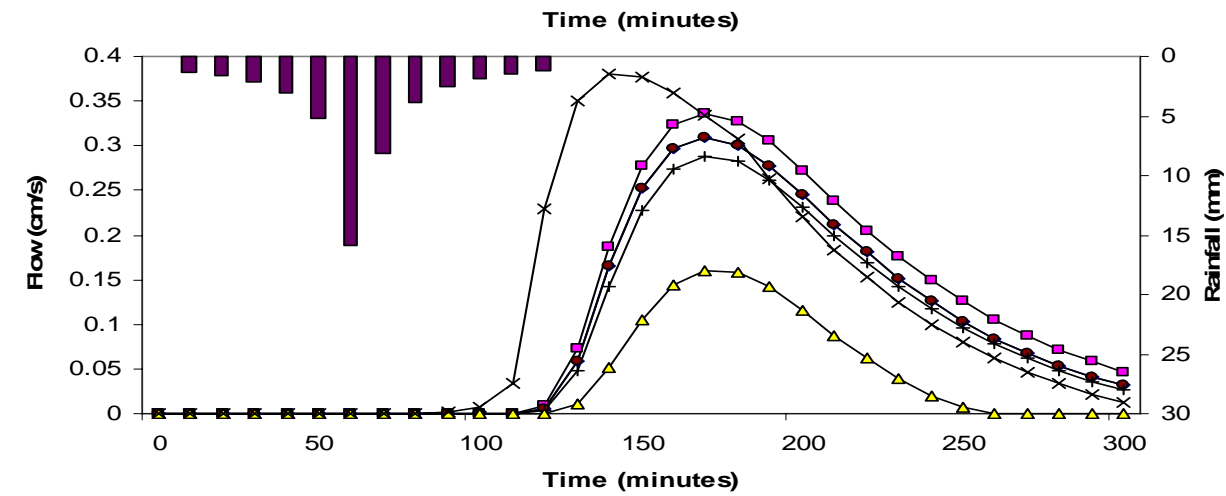

Rainfall (mm)

$\rightarrow$ OUTFLOW (no infil)

$\multimap$ OUTFLOW (clay infil)

- OUTFLOW (clay loam infil)

$\longrightarrow$ OUTFLOW (sandy loam infil) $\_$OUTFLOW (sand infil)

$\rightarrow$ STORAGE INFLOW

Fig. 4. Storage unit J2 outflow variation with different infiltration modeling scenarios. The inflow hydrograph to the storage unit is also shown.

\section{Incorporating infiltration modelling in urban flood management}

A. S. Jumadar et al.

\section{Title Page}

\section{Abstract}

Conclusions

\section{Tables}

14

4

Back
Introduction

References

Figures

$\rightarrow$

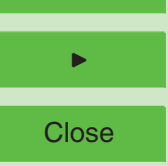

Full Screen / Esc

Printer-friendly Version 


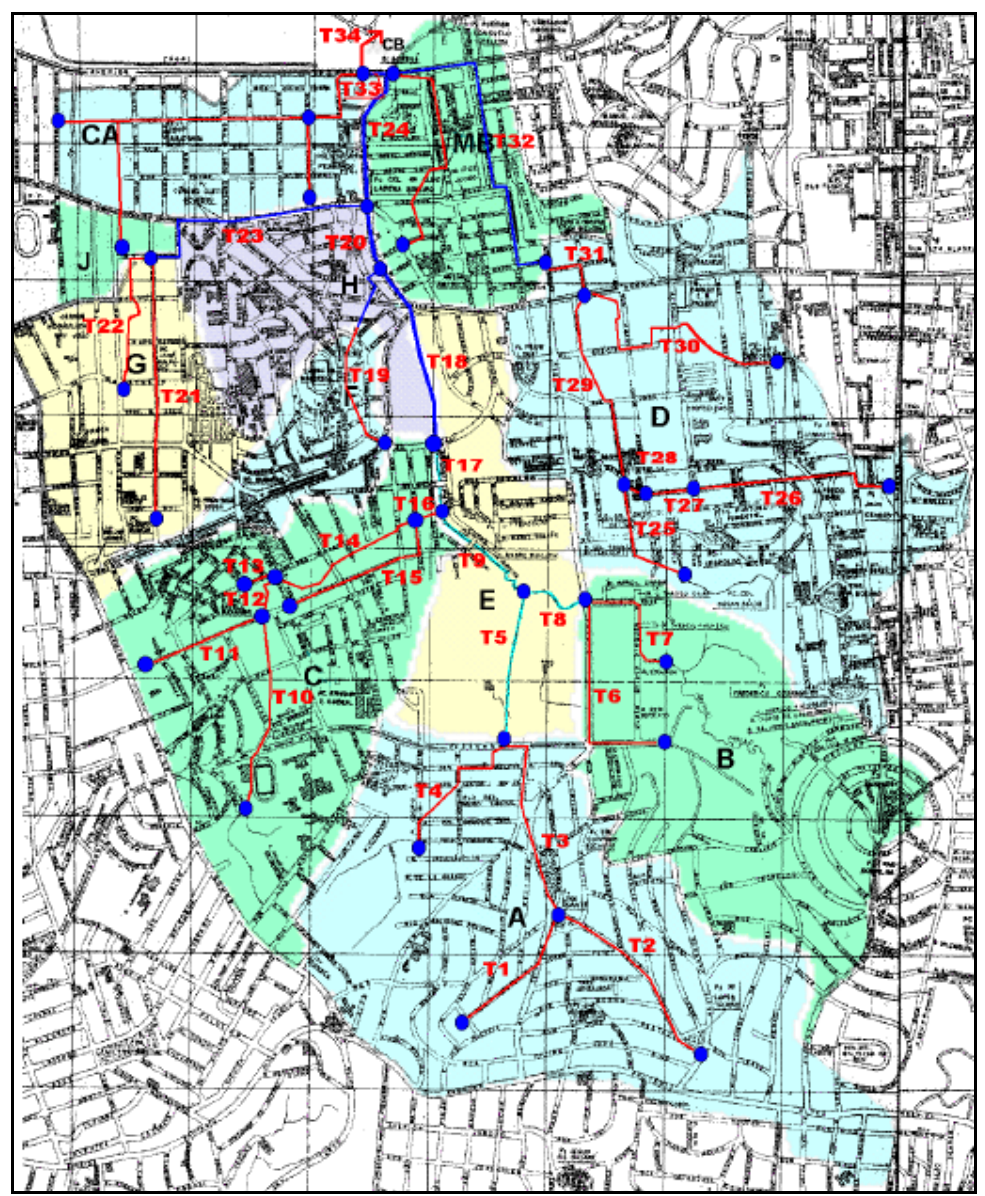

Fig. 5. Macro-drainage layout in Arroio da Areia basin in Porto Alegre (TUCCI, 2002).

\section{HESSD}

5, 1533-1566, 2008

Incorporating infiltration modelling in urban flood management

A. S. Jumadar et al.

\section{Title Page}

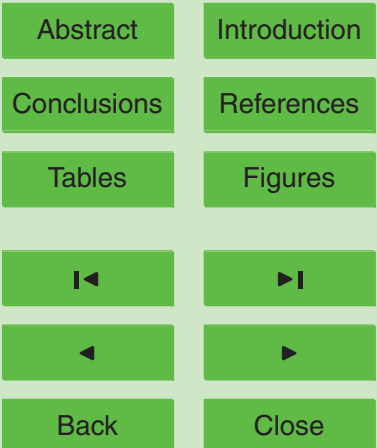

Full Screen / Esc

Printer-friendly Version

Interactive Discussion 


\section{HESSD}

5, 1533-1566, 2008

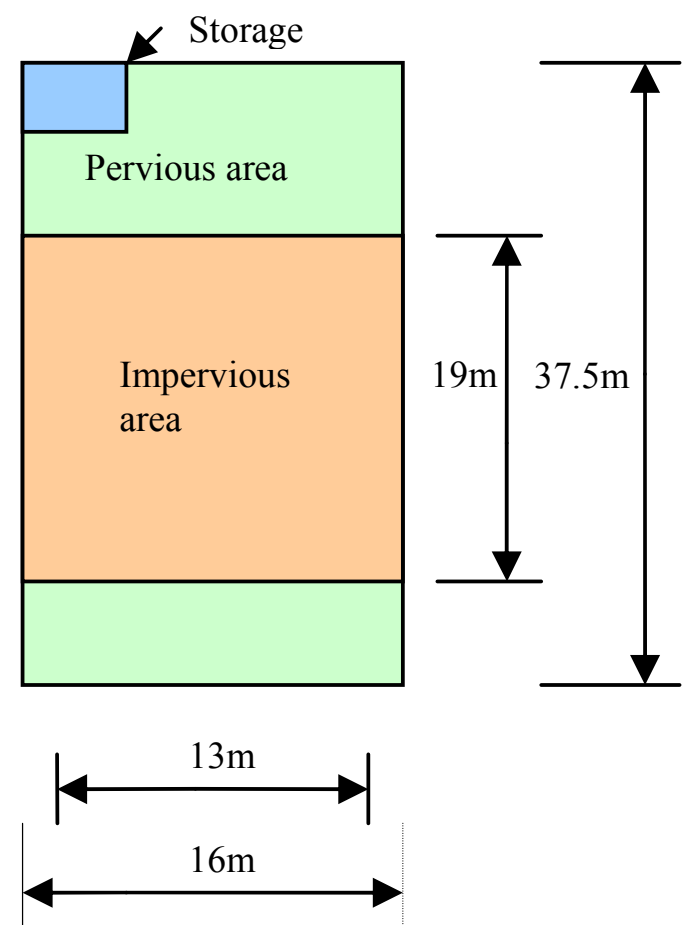

Incorporating infiltration modelling in urban flood management

A. S. Jumadar et al.

Title Page

Abstract

Introduction

Conclusions

References

Tables

Figures

14

$\rightarrow$ I

4

Back

Close

Full Screen / Esc

Fig. 6. Building lot physical dimensions.

Printer-friendly Version

Interactive Discussion 


\section{HESSD}

$5,1533-1566,2008$

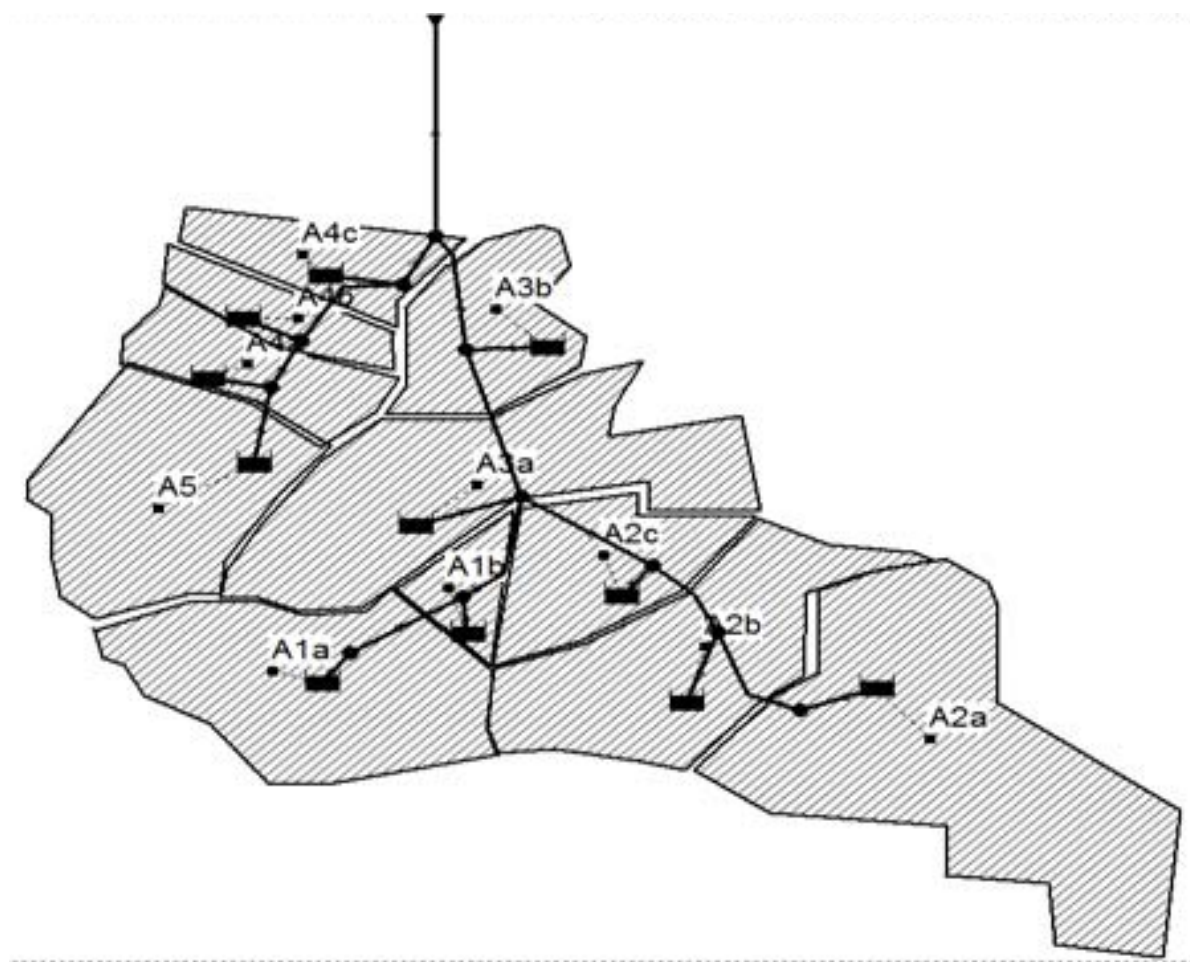

Fig. 7. Model set-up in Modified EPA-SWMM 5.0, for regional storages at sub-catchment level in sub-basin A.

\section{Incorporating infiltration modelling in urban flood management}

A. S. Jumadar et al.

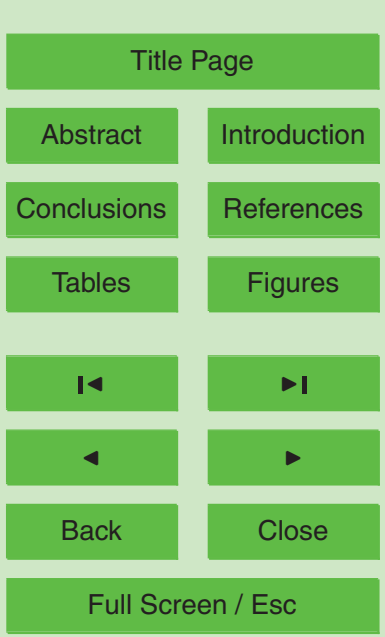

Printer-friendly Version

Interactive Discussion 


\section{HESSD}

$5,1533-1566,2008$

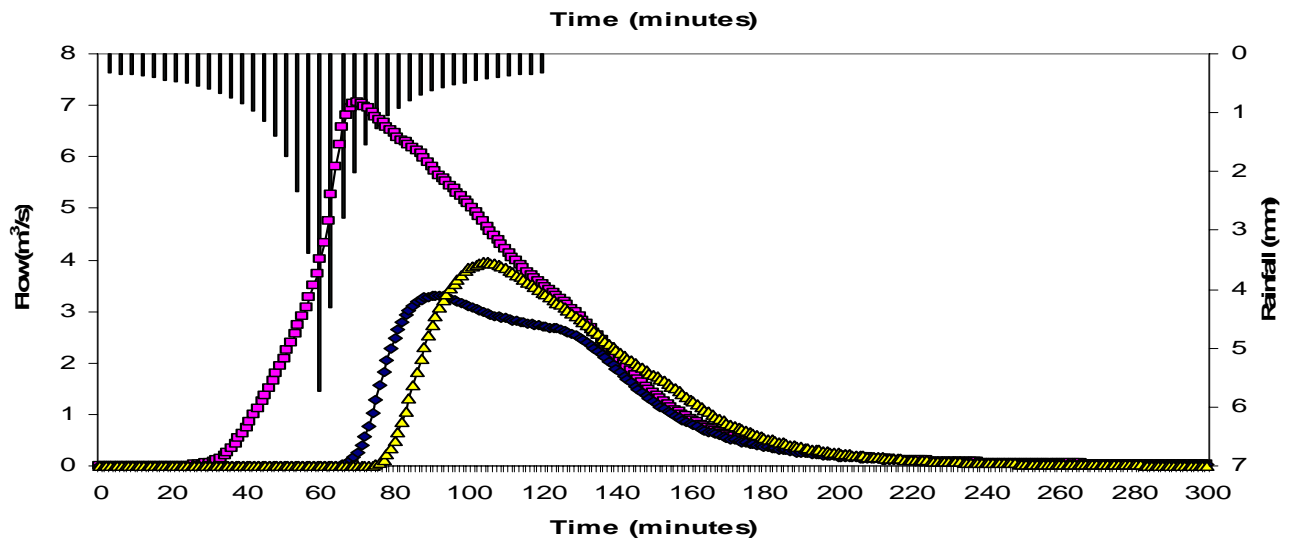

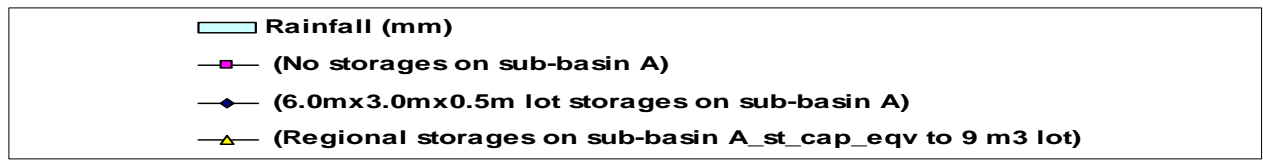

Fig. 8. Sub-basin A outflow hydrograph for $9 \mathrm{~m}^{3}$ lot storage and equivalent regional storage capacity scenario.

\section{Incorporating infiltration modelling in urban flood management}

A. S. Jumadar et al.

\section{Title Page}

\section{Abstract}

Conclusions

\section{Tables}

14

4

Back
Introduction

References

Figures

$\rightarrow$

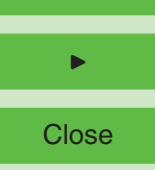

Full Screen / Esc

Printer-friendly Version 


\section{HESSD}

5, 1533-1566, 2008

Time (minutes)

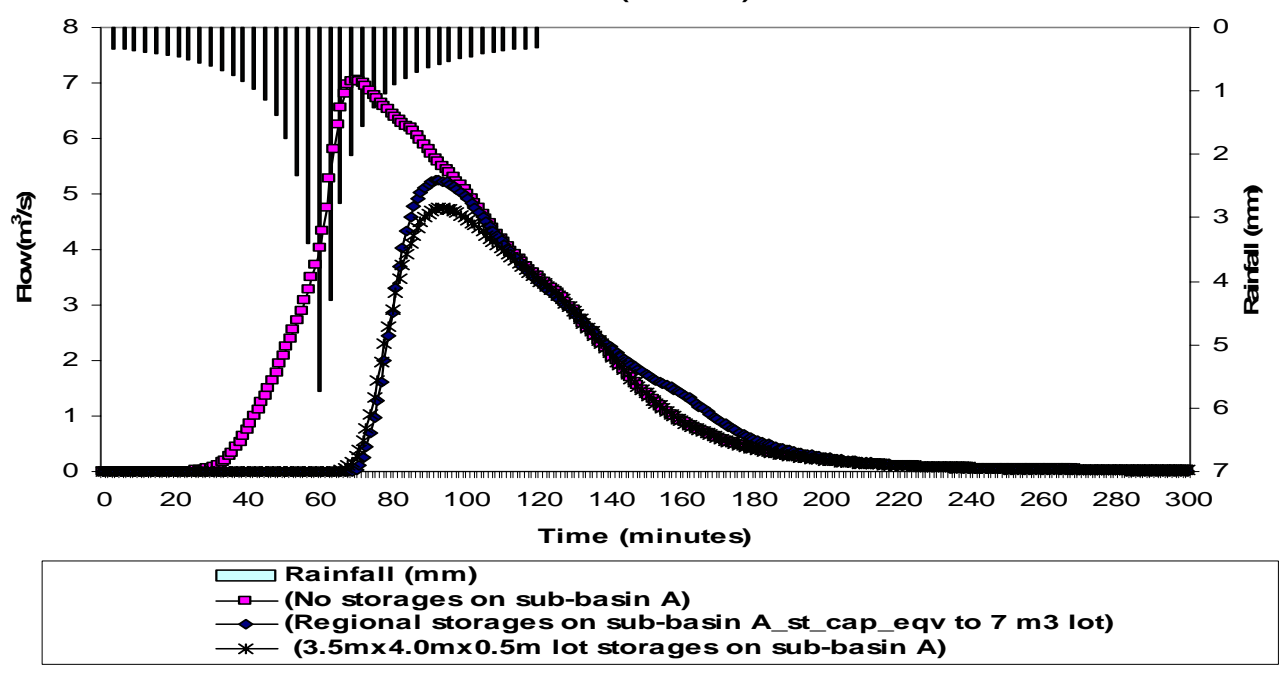

Incorporating infiltration modelling in urban flood management

A. S. Jumadar et al.

Title Page

Abstract

Introduction

Conclusions

References

Tables

Figures

14

$>$ I

4

Back

Full Screen / Esc

Printer-friendly Version

Interactive Discussion 


\section{HESSD}

5, 1533-1566, 2008

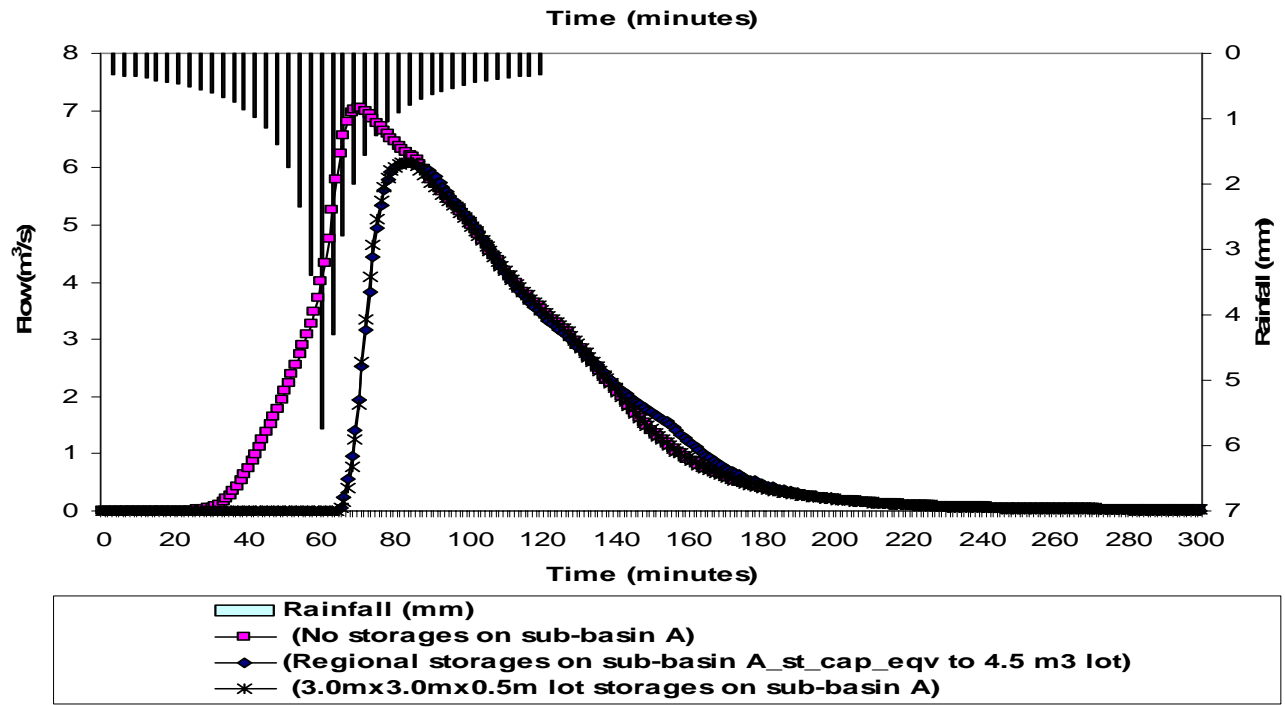

Incorporating infiltration modelling in urban flood management

A. S. Jumadar et al.

Title Page

Abstract

Introduction

Conclusions

References

Tables

Figures

14

$>$ I

4

Back

Full Screen / Esc

Printer-friendly Version

Interactive Discussion 


\section{HESSD}

5, 1533-1566, 2008

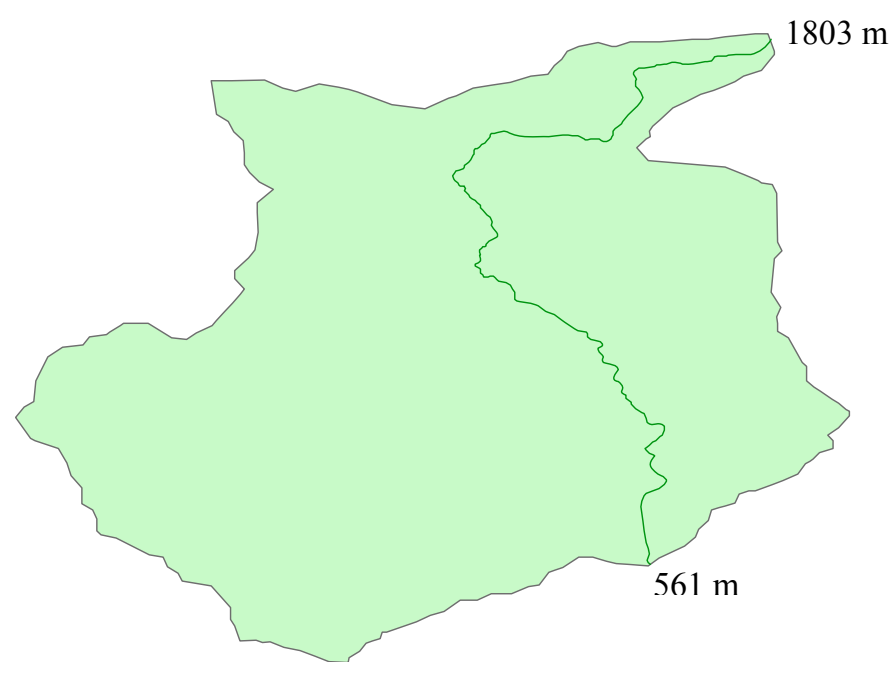

Incorporating infiltration modelling in urban flood management

A. S. Jumadar et al.

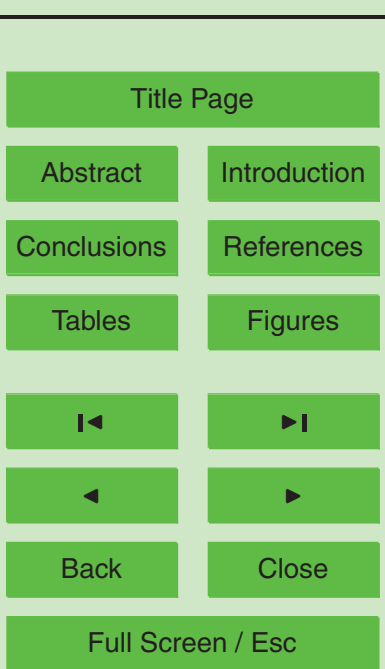

Printer-friendly Version

Interactive Discussion 


\section{HESSD}

$5,1533-1566,2008$

\section{Incorporating infiltration modelling in urban flood management}

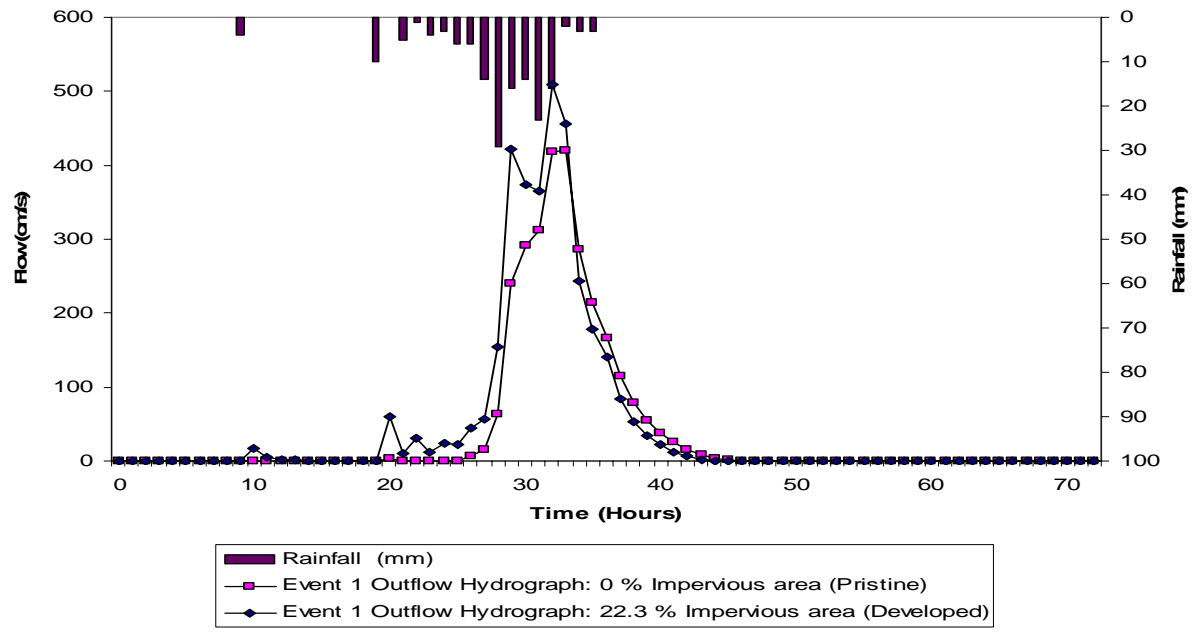

A. S. Jumadar et al.

Fig. 12. Aimata catchment runoff hydrographs for pristine and developed catchment.

Title Page

Abstract

Conclusions

Tables References

14

14

4

Full Screen / Esc

Printer-friendly Version

Interactive Discussion 


\section{HESSD}

$5,1533-1566,2008$

Time (Hours)

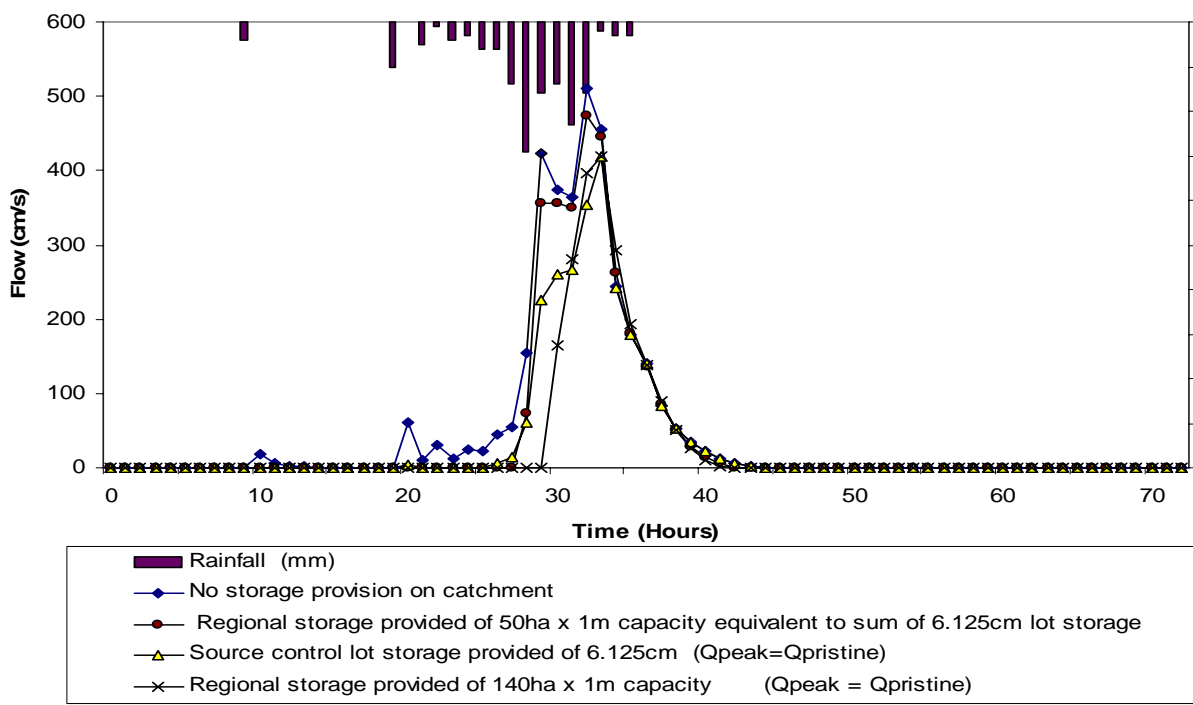

Fig. 13. Developed Aimata catchment runoff hydrographs for proposed storage options.
Incorporating infiltration modelling in urban flood management

A. S. Jumadar et al.

Title Page

Abstract Introduction

Conclusions

References

Tables

Figures

14

$>$ I

4

Back

Close

Full Screen / Esc

Printer-friendly Version

Interactive Discussion 